\title{
Imaginação: arte e ciência na infância
}

\author{
Gilka Girardello*
}

Resumo: $\mathrm{O}$ artigo faz uma breve discussão conceitual sobre a relação entre imaginação e infância, apontando alguns fatores considerados favoráveis à imaginação infantil: a arte, o tempo, a natureza, a mediação adulta e a narrativa. Investigam-se os processos infantis de criação de hipóteses diante dos fenômenos do mundo, destacando o papel que neles desempenham a curiosidade e a partilha narrativa. Examinam-se aspectos da vida imaginativa infantil, especialmente em contextos pedagógicos, explorando possibilidades de ação educativa - com ênfase para a narração oral — que integrem diferentes áreas do conhecimento de forma não dualista e que promovam a abertura de caminhos para a descoberta.

Palavras-chave: imaginação; arte; ciência; educação; infância; narrativa.

\section{Imagination: Arts and Sciences in childhood}

Abstract: This article conducts a brief conceptual discussion about the relationship between imagination and childhood, indicating factors considered favourable to children's imagination: the arts, time, nature, adult mediation and narrative. Processes children use to create hypotheses concerning worldly phenomena are investigated, highlighting the role of curiosity and narrative sharing. Aspects of children's imaginative lives are examined, especially in pedagogical contexts, exploring opportunities for educational action - with an emphasis on oral narratives - which integrate different fields of knowledge in a nondualist way and promote the opening of paths to discovery.

Key words: imagination; arts, science, education, childhood, narrative.

O papel permanente dos professores, e, em particular, da escola, consistiria em não fechar nenhuma porta ao impossível e demonstrar que os caminhos da imaginação

conduzem às vias da razão e vice-versa. (Jean, 1990, p. 214)

* Professora do Centro de Educação, coordenadora do Núcleo Infância, Comunicação e Arte e da Oficina Permanente de Narração de Histórias da Universidade Federal de Santa Catarina (UFSC), Brasil. gilka@floripa.com.br 
A imaginação é para a criança um espaço de liberdade e de decolagem em direção ao possível, quer realizável ou não. A imaginação da criança move-se junto - comove-se - com o novo que ela vê por todo o lado no mundo. Sensível ao novo, a imaginação é também uma dimensão em que a criança vislumbra coisas novas, pressente ou esboça futuros possíveis. Ela tem necessidade da emoção imaginativa que vive por meio da brincadeira, das histórias que a cultura lhe oferece, do contato com a arte e com a natureza, e da mediação adulta: o dedo que aponta, a voz que conta ou escuta, o cotidiano que aceita.

A importância da imaginação para a educação das crianças vai muito além da indicação de estratégias e recursos, fazendo sentido, a nosso ver, o manifesto de Georges Jean em defesa de toda uma "pedagogia poética" para a infância, aberta tanto à "vertigem quanto aos giros incertos dos labirintos" (Jean, 1990, p. 16)1. Este é o campo em que, segundo ele, a invenção pedagógica mais se impõe, sendo que o primeiro passo, nesse sentido, seria, "para o docente e educador, a invenção de si mesmos" (Jean, 1990, p. 12).

Por não se tratar de um dom ou de um dado objetivo e quantificável da subjetividade da criança, estando ligada à inteligência e às emoções, a imaginação infantil pode ser educada, como dizem muitos estudiosos a partir de diferentes perspectivas teóricas: "as crianças podem ser ensinadas a olhar e a ouvir de maneira a que a emoção imaginativa seja consequência”, diz Warnock (1976, p. 206-7); "assim como o entendimento lógico da criança, também sua habilidade de se envolver com o faz de conta e a fantasia precisa ser construída”, observa Gardner (1982, p. 182); "a imaginação, como a inteligência ou a sensibilidade, ou é cultivada, ou se atrofia”, diz Held (1980, p. 46); "a imaginação pode e deve ser educada, e a experiência que ela nos dá é mais importante e válida do que qualquer outra que possamos adquirir somente através do pensamento racional", diz Mock (1970, p. 136). "A tarefa mais importante da educação parece ser a educação da imaginação", para Sloan (1993, p. 158).

Se a compreensão de que a imaginação é fundamental na educação já parece assegurada na produção acadêmica em nosso país, na prática seu papel segue ainda muitas vezes associado prioritariamente ao campo da arte e do desenvolvimento estético, mantendo-se vivo em muitos contextos o preconceito dualista que em nossa cultura separa razão e emoção, afeto e intelecto, arte e ciência. Por isso, este artigo procura somar-se a outros trabalhos brasileiros recentes, no campo da educação das crianças, que buscam desmanchar esse muro, como é o caso de Pietrocola (2004), Barbosa (2007) e Laterman (2008). Assim, procuraremos compartilhar ainda outros argumentos para uma compreensão do quanto a expe-

1. As traduções das citações feitas neste artigo a partir de publicações em inglês e espanhol (ver referências) são minhas. 
riência imaginativa é vital para os caminhos da criança em seu processo integral de conhecimento do mundo, tanto em seus aspectos estéticos quanto científicos. Partimos de pressupostos teóricos bem conhecidos entre nós, como o de que a imaginação, por ser base de toda a atividade criadora, "se manifesta por igual em todos os aspectos da vida cultural, possibilitando a criação artística, científica e técnica" (Vigotsky, 2003, p. 10).

Partimos também de uma indicação feita por Calvino, de que precisamos de uma "pedagogia da imaginação", que nos permita "controlar a própria visão interior sem sufocá-la e sem, por outro lado, deixá-la cair num confuso e passageiro fantasiar" (1990, p. 108). Embora Calvino faça a ressalva de que uma tal pedagogia só poderia ser aplicada a nós mesmos, pois teria que ir sendo improvisada a cada instante, o fato é que, tanto na filosofia quanto na psicologia, na pedagogia e na teoria literária, encontramos indicações de condições propícias ao florescimento da imaginação da criança. Longe de tentar referir de forma exaustiva a grande produção no campo, limitar-nos-emos a indicar apenas os aspectos favoráveis à imaginação infantil que mais apareceram como consensuais na revisão de literatura que fizemos sobre o tema, parcialmente apresentada em trabalhos anteriores e aqui reelaborada.

\section{A arte, o tempo e a mediação}

Uma das condições mais frequentemente apontadas como favoráveis à imaginação é a possibilidade de fruição estética, especialmente o contato profundo da criança com a literatura e a arte. Maxine Greene, a partir da filosofia da educação, faz uma defesa apaixonada dessa perspectiva, dizendo que o envolvimento das crianças com a arte é o melhor antídoto contra o "congelamento do pensamento imaginativo" causado muitas vezes pelo "bombardeio de imagens da divindade da Comunicação Tecnológica” (1995, p. 124). Mas Greene observa que não basta a exposição da criança à arte para que haja o envolvimento, é necessário que ela receba um encorajamento delicadamente equilibrado que tanto a leve a "prestar atenção às formas, padróes, sons, ritmos, figuras de linguagem, contornos e linhas” (1995, p.125), como também que a libere para construir o significado particular que as obras possam ter para ela: "Mobilizar a imaginação das crianças em resposta a um texto [...] pode ser comprometê-las com a busca de possibilidades alternativas." (1995, p. 129).

A imersão na experiência da arte exige tempo, que é em geral outra condição benéfica para a vivência imaginativa da criança. $\mathrm{O}$ trabalho da imaginação é "quieto e sub-reptício" (Warnock, apud Egan, 1992, p. 158); ele se dá bem com a calma, a concentração, o isolamento, e mesmo com certo tédio, como diria Lewis Carroll, que escreveu na primeira linha de Alice no País das Maravilhas: "Alice estava can- 
sando de ficar sentada na beira do lago, com a irmã, sem nada para fazer" (Carroll, 2007, p. 11). Outra representação literária do poder desse tipo de vazio aparente de estímulos sobre a imaginação infantil são as situações de aborrecida sonolência que desencadeiam a viagem de Narizinho ao reino das Águas Claras e a aparição do Saci na vida de Pedrinho, na obra de Monteiro Lobato. A identificação de gerações de crianças com essas cenas sugere que reconheçam nelas o eco de uma experiência subjetiva que sentem como verdadeira.

"Um leve tédio", pondera Egan, permite que a mente relaxe e divague, permite liberdade mental e solidão, enquanto o aluno olha fixamente pela janela ou contempla os desenhos no teto" (Egan, 1992, p. 158). A imaginação é a capacidade de olhar "através das janelas do real" (Greene, 1995, p. 140), viabilizando na experiência o plano das possibilidades. Não por acaso a autora escolhe a cena do olhar pela janela em sua metáfora para a imaginação: o jogo, tão caro à infância, de ver animais e castelos nas nuvens, o rosto na lua cheia e paisagens fantásticas nos veios da madeira, precisa do ócio, de momentos sem pressa em que a imaginação possa atuar plenamente, nos interstícios da percepção. Diversas cenas de crianças devaneando à janela, olhando as nuvens, ou à beira do fogo, e até o relato de um menino que via a figura de uma mulher muito importante em sua vida imaginária em uma mancha de mofo no teto, constam da coleção de trechos da literatura sobre crianças, reunida por De Lauwe (1991, p. 92-127). A entrega à criação imaginativa sem pressa é uma forma de contemplação, que, segundo Mock, é dificultada pelo clamor auditivo e visual da agitação contemporânea (Mock, 1970).

Vemos aí uma importante indicação para o trabalho educativo. Isso porque, como diz Jean, "a escola, em muitos casos, proíbe a fulguração, assim como proíbe a lentidão e a paciência”. (Jean, 1990, p. 16). Nem sempre a criança que se mostra momentaneamente parada, com o olhar fixo e aparentemente vago, precisa naquele instante da interferência automática do adulto para que faça alguma coisa, para que se envolva com os colegas ou com alguma outra proposta em andamento na sala. Às vezes, ela pode estar em plena elaboração imaginária, vivenciando o devaneio, que é parte fundamental de sua vida subjetiva.

Outra dimensão importante da contemplação estética é o contato com a natureza, também citado frequentemente como um fator positivo para a imaginação da criança. Para Bachelard, a relação com a natureza é mesmo a grande matéria da imaginação infantil: "o devaneio na criança é um devaneio materialista. A criança é um materialista nato. Seus primeiros sonhos são os sonhos das substâncias orgânicas" (1994, p. 9), diz Bachelard, remetendo aos elementos — o fogo, o ar, a água e a terra - que para ele são "os hormônios da imaginação" (1990, p. 12). O estímulo imaginativo surge não só no contato com o que pode ser tocado ou percebido - como o calor do fogo, a viscosidade da lama — mas também no encontro com o incomensurável, como a multidão de estrelas no céu, o tamanho 
do mar, o poder das tempestades. É o assombro diante dos elementos e da infinita multiplicidade da natureza um dos fatores da emoção estética que Kant chamou de sublime, "a descoberta da profundeza infinita da imaginação" (Kearney, 1991, p. 175). Warnock destaca a importância dessa "emoção do infinito, ou da inexauribilidade das coisas" (1976, p. 207) na experiência estética das crianças. Um exemplo dessa emoção e da intensidade do que se vê pela primeira vez, bem como do papel do adulto na orientação da percepção infantil, é o relato feito por C.G. Jung a partir de uma de suas mais antigas lembranças de infância:

Era um belo fim-de-tarde de verão. Uma tia me disse: "Vou te mostrar uma coisa". Ela me levou para fora, em frente à casa, na estrada para Dachsen. No horizonte ao longe estava a cordilheira dos Alpes banhada dos vermelhos brilhantes do pôr-do-sol. Podiam-se ver os Alpes claramente naquela tarde. "Olhe lá" - posso ouvi-la dizendo no dialeto suíço _ _ "as montanhas estão todas vermelhas". Pela primeira vez eu via os Alpes conscientemente. Então me disseram que no dia seguinte as crianças da escola da vila iam dar um passeio até Uetlieberg, perto de Zurique. Eu queria muito ir também. Para minha tristeza, fui informado de que crianças pequenas como eu não podiam ir, nada havia a fazer. Daí em diante, Uetliberg e Zurique tornaram-se uma inatingível terra de sonhos, perto das montanhas brilhantes cobertas de neve. (Jung, 1989, p. 7).

O importante papel do adulto - ou mesmo da criança mais velha e experiente - na complexificação do encontro com o novo, o grande, o incomensurável, pode ser exemplificado pelo conhecido e primoroso conto de Eduardo Galeano (2003, p.15), em que o menino pede ao pai, diante do mar que vê pela primeira vez, que o ajude a olhar. Ajudar a olhar pode ser simplesmente estar ao lado da criança, acompanhando-a naquele momento de espanto. Pode ser também explorar ludicamente a situação, contando, por exemplo, que além da linha do horizonte, se remássemos cem dias e noites em uma canoa (como fez o navegador brasileiro Amyr Klink), chegaríamos a outra praia, onde outras crianças brincam, e quem sabe naquele exato momento uma delas também esteja contemplando o mar. $\mathrm{Ou}$ poderíamos dizer que, se caminhássemos mar adentro, vestindo trajes de mergulhador, iríamos descendo até chegar à beira de um penhasco submarino; e, se saltássemos dali ao fundo, chegaríamos a uma região tão profunda que nem a luz do sol a alcança, onde vivem peixes que trazem no corpo suas próprias luzinhas. Situações como essas fazem parte da alegria do convívio entre as gerações e são testemunho de que a imaginação e a informação podem andar juntas, alimentando mutuamente a curiosidade da criança. Nesse sentido, Zim (1966) comenta que 
não existe risco de que a informação destrua a beleza, a fantasia, a imaginação e a poesia: "Ninguém estará desmerecendo o mito, a fábula, a lenda ou a história de aventura ao deixar a criança perceber que o mundo real à nossa volta também está cheio de maravilhas, beleza, e coisas mais estranhas e curiosas do que somos capazes de imaginar" (Zim, 1966, s.p.).

$O$ poder sugestivo da natureza para a criança também se produz na escala mais doméstica e próxima dos jardins, quintais e parques. Metáforas como "jardim de infância" e "primavera da vida" têm uma conotação paradisíaca, de primeira felicidade. "O jardim faz parte da vida imaginária da criança, [mas] mesmo que a criança não tenha a sorte de viver em um jardim, um pequeno recanto de natureza lhe é suficiente para recriar seu mundo imaginário", assinala De Lauwe (1991, p. 268-9). No jardim, a criança é livre para devanear e falar com amigos reais ou fictícios, resguardada do olhar adulto; é livre para compor mundos inteiros com pedras, sementes e insetos, encontrando a multiplicidade das formas e a imprevisibilidade do comportamento dos organismos. A relação da criança com a natureza é animista, lembra Held, "ela dá vida ao que toca" (1980, p. 39).

Assim, a criança que vê duas formigas carregadeiras cruzarem-se em uma microtrilha em meio ao gramado, movendo suas patinhas e antenas, poderá ficar se perguntando: "o que estarão elas conversando?" E quando as vê entrarem formigueiro adentro, poderá ficar pensando em como será aquele palácio subterrâneo, com seus salōes e corredores. O efeito da natureza sobre a imaginação das crianças não se limita, portanto, ao contato com a imensidão e o infinito, ocorrendo também diante de evidências singelas como um grão de feijão plantado em algodão úmido no copinho de iogurte, na janela da cozinha. Diante dos olhos maravilhados da criança, a cada manhã aparece ali uma novidade: a película abre-se, um broto surge e eleva-se na direção da luz, uma pequena raiz abre caminho para baixo. Como é que a planta sabe o que precisa fazer? Será que ela sente o toque da luz ou prova da água que absorve do algodão? E se o pé de feijão crescesse até as nuvens, como seria? Naquele canto da cozinha, sem que ninguém à sua volta perceba, a criança elabora hipóteses em silêncio, cria estratégias e enredos a partir do que já conhece, experimenta a liberdade radical da imaginação que, movida pela curiosidade e assegurada pelos adultos em seu ambiente, dá-lhe base para formulações cada vez mais complexas em seu conhecimento do mundo.

A atitude dos adultos no ambiente em que a criança vive, assim, é outro fator de influência sobre a imaginação. O papel dos adultos como mediadores entre a criança e o ambiente físico e o clima social criados pela família ou pelas instituiçóes educativas fazem diferença na qualidade da vida imaginativa dos pequenos. Singer e Singer observam que as habilidades necessárias para a atividade do faz de conta podem ser estimuladas pela intervenção adulta, devendo, no entanto, haver um equilíbrio entre a estruturação das atividades pelo adulto e a possibilidade de que 
as crianças possam brincar sozinhas, livres de supervisão: "O faz-de-conta emerge naturalmente como parte do desenvolvimento da criança pequena, mas seu florescimento é encorajado quando os pais e outros adultos contam histórias, lêem em voz alta ou interagem ludicamente com as crianças" (Singer; Singer, 2007, p. 165).

Em outro estudo realizado por Singer e colegas (1984), a partir dos relatos de crianças de oito anos sobre companheiros imaginários e brincadeiras de faz de conta sugere-se que a maior imaginatividade aparece em ambientes com rotinas estruturadas, com familiares que valorizam a curiosidade, a criatividade, a narração de histórias e a variedade cultural; e que preferem métodos de indução (não autoritários) no trato com as crianças. Outro estudo, realizado por Schaeffer, Gold e Henderson (1986), acrescenta que os familiares que apoiam as fantasias dos filhos e que estão em contato com sua própria vida de fantasia parecem ter crianças com uma vida imaginativa rica e prazerosa. Vemos aí mais um argumento a favor da ideia afirmada anteriormente por Georges Jean (1990), de que uma pedagogia imaginativa requer também dos educadores uma reinvenção de si próprios, para que abram espaço e tempo em suas vidas para as experiências da imaginação.

Um aspecto frequentemente negligenciado da mediação adulta sobre a vida imaginativa das crianças é o papel ativo que nela desempenham as próprias crianças. É comum que, quando uma pessoa adulta se aproxima de uma criança, tenda a buscar em suas próprias lembranças de infância as histórias e as brincadeiras que preferia. Entre todas as canções de roda que chegou a conhecer de cor quando pequena, por exemplo, ela provavelmente lembrará daquelas que a criança que ela foi um dia mais apreciou. Da mesma forma, as histórias que ela repetirá à criança de hoje tenderão a assemelhar-se com as que mais prazer ou auxílio lhe trouxeram quando era pequena. Os misteriosos critérios da preservação cultural de certas histórias ou brincadeiras têm relação com isso. Podemos não ter a mínima ideia de por que gostávamos de determinado conto, mas permanece a impressão que ele causou à criança que fomos. Esse fenômeno foi percebido por Chukovsky:

Apesar de cada nova geração de pais e mães cantar e recitar para as crianças tanto o bom quanto o inferior, só o que melhor atende às necessidades e gostos das crianças permanece em suas memórias. E quando chegar à idade avançada, todo aquele que ouviu canções folclóricas passa para seus netos, por sua vez, apenas as melhores delas, as mais vívidas e vitais. Tudo que está fora de sintonia e é incongruente com a psicologia da criança pequena é gradualmente esquecido e se torna extinto. (Chukovsky, 1968, p. 94).

Assim, seriam de certo modo as crianças de uma geração que contam histórias e propõem brincadeiras às crianças da geração seguinte. Para transpor essa compreensão para os cenários atuais seria preciso, é claro, considerar também o papel 
da escola e das mídias na mediação cultural ao cotidiano infantil. Mas a ideia de crianças passando as imagens e as histórias que mais amam às crianças da geração seguinte, como numa corrida de revezamento, tem o mérito de chamar atenção para essa outra forma de transmissão cultural entre crianças — a longo do tempo, através das gerações.

A narrativa, por fim, desempenha um papel dos mais importantes na vida imaginativa infantil, e por isso será examinada com maior detalhe a seguir, ressalvando que no cotidiano da criança todas essas circunstâncias evidentemente agem em conjunto.

\section{A narrativa e a imaginação infantil}

Um laço indissolúvel une a narrativa à imaginação, e as crianças têm necessidade das imagens fornecidas pelas histórias como estímulo para sua própria criação subjetiva, para sua exploração estética e afetiva dos meandros do mundo. A necessidade de histórias tem sido identificada como um aspecto central na vida imaginativa das crianças. As histórias permitem um exercício constante da imaginação em seu aspecto mais visual. Isso ocorre tanto em relação aos contos literários quanto aos casos contados no meio das conversas, tão apreciados pelas crianças. Cada uma delas imaginará um pássaro diferente ao ouvir contar $O$ rouxinol do imperador, de Andersen, e verá cenas mentais únicas ao ouvir o relato das andanças da tia pelo centro da cidade. A força do apelo visual é um dos critérios para o interesse gerado nas crianças pelas histórias, literárias ou informais. Chukovsky recomendava aos escritores de livros para crianças que "pensassem por imagens" (1968, p. 145), ou seja, que cada linha que escrevessem fosse capaz de sugerir uma ilustração, para auxiliar a viagem imaginária dos pequenos leitores. A visibilidade — a capacidade de sugerir imagens mentais - é uma das qualidades narrativas mais importantes, como enfatiza Calvino (1990). É essa uma das qualidades que torna memoráveis as histórias e que está na base da função do mito nas culturas tradicionais, como mostram as culturas orais que "sempre ligaram sua sabedoria a imagens vívidas, envolvendo-as em histórias que conseguiam despertar respostas afetivas” (Egan, 1992, p. 70).

Para explorar o significado profundo da narração de histórias nas escolas e nos espaços de educação infantil, podemos recorrer a uma metáfora: os momentos em que se contam histórias nas salas de aula são como clareiras num bosque. Suponhamos um pouco mais: em meio ao zum-zum das crianças forma-se um círculo, no fundo da sala, em cima de um tapete ou de almofadas de algodão que passaram a manhã tomando sol no beiral da janela. Com olhos arregalados e risadinhas, as crianças aconchegam-se e escutam a voz da moça de jeans ou vestido floreado - a professora. Entram na história que ela conta, quase fecham os olhos, feito estátu- 
as. Mas, ao contrário do que parece, elas não estão nem um pouquinho paradas: cavalgam num corcel veloz, ocupadíssimas com aventuras muito longe dali.

A ideia de que a imaginação é uma espécie de "clareira luminosa" aparece na obra de pelo menos dois filósofos contemporâneos importantes neste campo: Eva Brann (1991) e Paul Ricoeur (1978). Para este, a imaginação cria esse espaço de mediação, que ele chama de clareira, onde podemos comparar os nossos desejos e demandas éticas com as do outro. Só por isso já faria muito sentido abrir e manter aberto o espaço para as histórias nas escolas, já que o estímulo narrativo é um dos mais poderosos hormônios da imaginação. Mas é claro que há muito mais. A imaginação alimenta-se de imagens novas e por isso talvez ela seja tão acesa nas crianças, para quem tantas imagens são novas. Assim, a escuta literária das crianças deve ser pelo menos tão intensa quanto a nossa leitura literária de adultos, e talvez o seja muito mais. Essa escuta é o broto do amor pela literatura, que tanta felicidade e sentido poderá trazer à vida delas, nos seus anos de infância e futuro afora.

Exploremos um pouco mais a metáfora da clareira: podemos considerar que a vida de cada uma daquelas crianças na sala de aula seja como um bosque úmido de folhas e galhos, cheio de aventura, perigo, romance, heroísmo, medo, rotina e todos os outros matizes da condição humana. Quando as crianças brincam umas com as outras, cada bosque se entremeia ao outro, formando um só: a experiência cultural da infância. Nos espaços educativos, essa cultura é fértil, brota o tempo todo, no cochicho da menina com a amiga da mesa de trás, no menino que mostra ao colega o desenho que fez. Contar e ouvir histórias age como uma pequena clareira nesse bosque, um espaço onde se vê a luz das estrelas, onde as crianças podem exercitar de forma especial seus poderes de enxergar longe, além do que a vista alcança. Longe em anos-luz e longe no tempo, desde o passado mítico ao futuro intergaláctico. E podem exercitar, ao mesmo tempo, a possibilidade de sentir-se radicalmente perto de si próprias, enquanto a batida dos corações acelera, e os pelinhos dos braços arrepiam de emoção.

Um ponto de partida para a criação dessa "clareira" é a preparação imaginativa da performance, pela professora. Se ela vai contar a história de Rapunzel, precisa enxergar mentalmente a torre onde a personagem fica prisioneira da bruxa. Todos sabemos que a torre é alta, mas é preciso ver se ela é alta como um poste de luz, alta como um prédio de cinco andares, ou tão alta que fura as nuvens do céu. Por que é necessária toda essa exatidão? Não será perigoso exagerar nos detalhes, descrever demais? Com certeza. Sobre isso, gosto muito de um caso relatado por Marie Shedlock, sobre um dia em que ela estava contando uma passagem da Ilíada, o duelo entre os guerreiros Ulisses e Polifemo:

justo no momento mais dramático, da história, um impulso que não tenho como explicar me levou a embarcar em uma descrição minuciosa da aparência física de Ulisses. As crian- 
ças foram ficando visivelmente entediadas, mas com bons modos seguiram escutando a minha elaborada descrição do herói. [...] Até que foram se desconcentrando, começaram a se remexer nas cadeiras, até que finalmente uma menininha da primeira fila, como porta-voz do grupo, disse de repente: "Será que a senhora podia, antes de continuar... será que a senhora não se importa de nos dizer se afinal aquele...aquele Poli...Poliforme morreu?”. (Shedlock, 1951, p. 5).

Voltando a Rapunzel: a narradora precisa saber a altura da torre, não para explicar isso em palavras às crianças, mas para saber para onde e como olhar para ela (apertando os olhos míopes para enxergá-la de longe?; colocando a mão na testa para que a luz vinda das alturas não a ofusque?). Precisa também saber como é a voz com que o príncipe vai chamar sua amada, se um sussurro clandestino ou um trovejar: Rapunzel! Joga-me tuas tranças!. Do mesmo modo, se ela conta uma história de Natal, precisa enxergar a gruta onde nasce o menino, sentir sua umidade, ver se há estalactites pendendo do teto. Precisa ver de que lado da manjedoura está Maria, de que lado estão o boi e o burrico. Ela não vai falar disso, necessariamente, mas precisa enxergá-lo. Assim, quando contar, por exemplo, que a jovem mãe ninou carinhosamente o Jesusinho nenê, que o boi o aqueceu com sua respiração, não terá dúvidas sobre em que direção se inclinará, sugerindo os movimentos dos personagens, e para que lado eles vão olhar. São detalhes singelos, mas essenciais, porque ajudam a criança a construir o filme mental sugerido pela narração, e porque ajudam a professora a ter confiança no que está contando.

Digamos que num conto de fadas o rei fale à multidão. Podemos detalhar essa indicação de muitas formas diferentes: ele pode, por exemplo, ir até a janela, abrir pesadas cortinas de veludo vermelho e depois as portas da sacada, apoiar as mãos solenemente no parapeito, pigarrear, olhar os súditos aglomerados na praça e começar seu discurso. Ou então pode, talvez, aparecer no alto de uma grande escadaria e ouvir impassível a trombeta do arauto e o anúncio de que vai falar Sua Majestade, o Rei! Ou pode ser um rei mais decarne e osso, que sobe em uma pedra e é ouvido só pelos mais próximos, que vão repassando suas palavras aos outros até que elas cheguem ao povo inteiro.

A exploração cenográfica imaginária do enredo é uma das etapas mais interessantes da preparação de uma história para contar. Qual a cor do céu? Que objetos há em cada cena, qual a mobília de um aposento, como estão vestidos os personagens? Se na história há um mar, podemos imaginá-lo transparente e ensolarado como o do Caribe, ou frio e cor-de-café-com-leite como o das praias gaúchas. Montanhas podem ser pontiagudas ou arredondadas. Uma viagem de carruagem pode ser veloz como um raio ou lenta e sacolejante, dependendo de como enxergarmos subjetivamente o estado da carruagem, da estrada e da idade dos cavalos que a puxam. 
De como visualizarmos esses detalhes dependem a sensação física sugerida pela descrição da heroína que se atira ao mar, o traçado da montanha feito no ar pelas mãos da professora, a trilha sonora de onomatopéias para o andar da carruagem.

Muitos detalhes das cenas precisam ser criados mentalmente pelo narrador antes de contar uma história pela primeira vez. Outros vão sendo reimaginados a cada vez que ela é contada de novo, do mesmo modo como a criança reimagina a cada vez que escuta. Assim como nunca se atravessa duas vezes o mesmo rio, também nunca se passa duas vezes pelas cenas de uma história, e surpresas sempre nos esperam a cada nova visita ao castelo da princesa Vasilissa, ao mercado de Bagdá, às vilas do sertão de Malasartes. Ou seja, o trabalho de criação imaginária, numa partilha narrativa entre adultos e crianças, dá-se necessariamente em mão dupla, ou não se dá.

Não só a ficção, mas toda a formulação narrativa dada a um conteúdo tem a capacidade de envolver a criança emotivamente, o que facilita a sua mobilização imaginativa, como diz $\mathrm{Egan}^{2}$. A brincadeira e a arte criam um espaço onde os conflitos podem ser expressos, tornando possível sua transformação, dizem Rustin e Rustin (1987). Eles destacam a importância da dimensão imagética da narrativa, dizendo que os significados simbólicos das histórias se expressam através de "associações de imagens que reverberam ao longo da história”, além de personagens com os quais a criança pode se identificar — como animaizinhos vulneráveis. Nas melhores obras para crianças, dizem eles, "as histórias não agem só ao nível do enredo, mas através das imagens e de sua transformação", que lhe acrescentam ressonância e profundidade metafóricas. (Rustin; Rustin, 1987, p. 13).

Segundo Rustin e Rustin, muitas formas típicas de estruturação da experiência, inclusive as que correspondem à compreensão psicanalítica, podem ser apreendidas com mais profundidade em um texto metafórico, poético, do que em um "naturalismo social de superfície". Para eles, os métodos de descoberta através da ficção criativa "não ficam devendo nada aos procedimentos mais dedutivos ou científicos. Eles geram descrições do mundo igualmente verdadeiras e em geral muito mais interessantes, em seu modo imaginário" (1987, p. 16). Isso nos ajuda a entender o porquê da fascinação das crianças pelas histórias: através do prazer que sentem na experiência poética, estão no fundo trabalhando, ou seja, cumprindo sua tarefa fundamental de conhecer o mundo e criar dele uma representação em cuja verdade confiam.

A pesquisa sobre o cotidiano imaginativo das crianças envolve dificuldades específicas, dada a impalpabilidade do objeto, que dificulta o uso de métodos experimentais convencionais. Todo o avanço da ciência não tornou a imaginação menos misteriosa do que era para Aristóteles, Kant ou Freud, e o estudo da

2. Idem. 
criança já foi comparado ao estudo antropológico de outro povo, tal a delicadeza interpretativa que requer, sem nenhuma garantia de compreensão. Há, mesmo assim, algumas tentativas recentes de descrição, senão dos processos, ao menos do conteúdo de produçôes infantis entendidas como indícios de atividade imaginativa. Uma delas é o trabalho de Egan (1992) sobre a vida imaginativa de crianças em idade escolar, que faz uma ponte interessante entre o cotidiano da criança e a reflexão filosófica sobre a imaginação, procurando descrever o que ele considera as principais características da imaginação das crianças. Seu conceito de imaginação diz respeito à "capacidade de pensar nas coisas como elas poderiam ser", à "fonte da invenção, da novidade, da geratividade.” (1992, p. 43). A imaginação para ele é "um tipo particular de flexibilidade, energia e vivacidade que vem da habilidade de pensarmos no possível, e não apenas no real, e que pode imbuir todas as funçōes mentais." (1992, p.65). É um conceito equivalente à dimensão de reservatório do potencial, inspirada em Calvino, que estamos atribuindo à imaginação neste trabalho. Uma pedagogia da imaginação, para Egan, implicaria estimular as crianças a irem além das ideias convencionais, um passo necessário para a apropriação individual do conhecimento adquirido: "Aceitar as representações convencionais é deixar de fazer do conhecimento nossa propriedade, é mantê-lo inerte em vez de incorporá-lo a nossa vida.”. (1992, p. 48).

Para Egan, a vida imaginativa típica de uma criança de cinco anos tem características diferentes da de um adolescente de quinze anos, embora haja semelhanças. Um dos traços que Egan identifica na imaginação infantil é a sedução pelos extremos e limites da experiência humana: "os atos mais corajosos ou os mais cruéis, os fenômenos naturais mais estranhos e bizarros, os eventos mais terríveis e os mais maravilhosos" (1992, p. 73) tendem a cativar especialmente a imaginação da criança em fase escolar. Segundo Egan, essa característica não é sempre levada em conta na elaboração dos currículos e dos materiais didáticos, que frequentemente procuram apenas desenvolver o conhecimento do ambiente local e das experiências familiares, enquanto "quanto mais distante e diferente da experiência cotidiana das crianças alguma coisa for, mais atraente à sua imaginação ela tenderá a ser." É claro que o conhecimento local é de primeira importância, esclarece Egan, mas deve haver uma dialética entre o familiar e o exótico: "A ênfase nos extremos e nos limites não nos afasta da experiência cotidiana, mas nos permite vê-la sob uma nova luz." (1992, p. 73).

Outra característica da imaginação da criança, segundo Kieran Egan, é o envolvimento com o arquétipo romântico do herói, que permite à criança pensar nela mesma como capaz de transcender os limites impostos pela vida real, triunfando sobre "as forças da opressão". Egan observa que a criança tende a encontrar estímulo e significado no conhecimento e na informação que vierem filtrados por um ângulo de "interesse humano", ou seja, através de emoções, ações, esperanças e medos humanos. 
O que torna as vidas dos outros significativas para nós é nossa habilidade de compartilhar imaginativamente de suas emoçōes, medos, esperanças, intenções, etc. Pensar nelas como se fossem nossas; e expandir as nossas ao pensar nelas como se fossem alheias. (Egan, 1992, p. 64).

Todas essas características podem ser resumidas na tendência que Egan aponta como primordial na imaginação da criança, já mencionada acima: a de ser prontamente estimulada por histórias — a conexão narrativa.

Arte e ciência, imaginação e curiosidade

Uma educação da infância que enfatize a imaginação pode contribuir para desmanchar o preconceito dualista que em nossa cultura ainda separa radicalmente a razão da emoção, a sensibilidade do intelecto. Isso vem sendo destacado ao longo dos anos por muitos autores, como Bronowski: "Um dos preconceitos modernos mais destrutivos é o de que a arte e a ciência sejam interesses diferentes e incompatíveis" (Bronowski, 1978, p. 3); e Barbosa: "Uma pedagogia que não separe a formação de cidadãos/trabalhadores/poetas, gente que tenha razão e coração, é o que move a criação de uma pedagogia do imaginário" (2007, p. 138). Sabemos da importância daquilo que Atalay, em seu estudo sobre o quanto a obra artística e a obra científica de Leonardo da Vinci estimularam-se mutuamente, chama de fecundação cruzada - entre as artes visuais e as ciências naturais, entre a música e a matemática, etc.: "Nisso reside uma lição eterna; em qualquer campo, os avanços momentosos se dão de modo mais afetivo quando o catalisador é a fecundação cruzada com outros". (Atalay, 2007, p. 323).

Nesse sentido, Chukovski (1968) relata, em um livro sobre o período dos dois aos cinco anos de idade na vida das crianças, a batalha que travou no final dos anos 1920 em defesa dos trava-línguas, poemas nonsense e contos de fada, estes especialmente abominados pela burocracia escolar stalinista. Um de seus argumentos era o de que o grande biólogo Charles Darwin fora, quando menino, tal fantasiador que todos o julgavam mais maluco que o Barão de Munchausen. E acrescenta:

Sem a fantasia imaginativa haveria completa estagnação tanto na física como na química, porque a formulação de novas hipóteses, a invenção de novos implementos, a descoberta de novos métodos de pesquisa experimental, a conjetura de novas fusōes químicas - todas são produtos da imaginação e da fantasia. (Chukovsky, 1968, p. 124).

Ele conta, por exemplo, o caso de um menino moscovita de cinco anos, cuja mãe, também pedagoga, desejava acostumar com as verdades da vida e por isso contou-lhe muito cedo sobre a concepção e o nascimento dos bebês: "Depois de ouvir a preleção da mãe, ele imediatamente torceu os fatos científicos à vontade, 
contando-lhe que quando estava dentro da barriga dela ele brincava em um jardinzinho, e tomava chá com o titio, que também passava uma temporada ali" (Chukovsky, 1968, p. 123). O menino estava praticamente dizendo à mãe, diz o autor, que naquele momento precisava mais de um conto de fadas do que de uma lição de embriologia, a fim de poder viver aquele período tão importante de seu desenvolvimento psicológico "de modo mais pleno, maravilhoso, e suntuoso" (Idem).

Ao mesmo tempo, Chukovsky defende a atenção às perguntas infantis e o esforço em dar respostas respeitosas e dialógicas à incansável curiosidade das crianças, em sua condição de pequenas exploradoras do mundo. Ele transcreve as perguntas feitas por um menino de quatro anos ao seu pai, uma atrás da outra, em um período de dois minutos: "Para onde a fumaça voa? Quem balança as árvores? Existe um jornal tão grande que consiga embrulhar um camelo? O polvo nasce de um ovo ou é mamífero? As galinhas saem na chuva sem galochas?” (Chukovsky, 1968 , p. 30). Perguntas como essas soam familiares para qualquer um que conviva com crianças pequenas, e por mais difícil ou cansativo que eventualmente possa ser respondê-las, é muito importante tentar fazê-lo. Diz Chukovsky: "Nosso dever, como educadores, é não apenas responder às infinitas questôes das crianças, mas também estimular ativamente a curiosidade delas, para que, de um ano para o outro, e às vezes de um mês para o outro, essas questôes se tornem mais e mais interessantes". (Idem, p.32).

"Responder com habilidade às perguntas das crianças", dizia Máximo Gorki, "é uma arte; requer cautela” (Apud Chukovsky, 1968, p. 32). Ele se referia ao cuidado em não explicar de menos nem demais, por um lado satisfazendo à inquietação da criança, mas sem, por outro lado, aborrecê-la com explicaçôes científicas incompreensíveis para ela. O desafio está em que, como sabem muitos professores, só quando precisamos explicar singelamente algum processo ou fenômeno para as crianças é que percebemos o quão pouco conhecemos sobre ele. Entre os caminhos que podem nos ajudar, enquanto educadores diante de desafios como estes, estão a pesquisa - que pode ser feita em conjunto com as crianças - e a busca experimental de linguagens adequadas ao interesse e à compreensão das crianças, para falar-lhes sobre as coisas do mundo de modo a seguir cativando sua imaginação e mobilizando sua curiosidade.

$\mathrm{Na}$ busca de linguagens enriquecedoras nesse sentido, já mencionamos a forma narrativa. Outra referência interessante podem ser as sugestôes de escritores de livros de ciência voltados às crianças, como as sintetizadas abaixo:

a. Uso de analogias: "Imagine uma bola bem redonda. Agora imagine essa bola navegando pelo espaço sem fim, de vez em quando batendo nas coisas, mas sem ir a nenhum lugar em especial. No espaço não existe nem em cima, nem embaixo. Pois há muitos animais que vivem assim, soltos no espaço”. 
b. Uso de metáforas: "os micróbios são os recicladores da natureza".

c. Uso dos pronomes você e eu como forma de envolver o leitor: "Acabei de ver um ratão do mato: macio, liso, com o focinho comprido. Vou tentar desenhá-lo".

d. Uso de comparações: "Nesta selva em miniatura no fundo do mar, o cavalo-marinho vai se agarrando com o rabo a uma alga e a outra, como um macaco pulando de galho em galho".

e. Propostas de experimentação: Você pode criar seus próprios micróbios. Pegue um guardanapo de papel...”

f. Perguntas: "Você já pensou que existem pedaços de montanha na sua casa? Não só as pedrinhas que você chuta no pátio, mas as que seguram sua casa em pé. Ou os minerais que você salpica na comida. Ou as pedras que você usa para escovar os dentes".

g. Uso de frases claras e simples: "Mas de onde vem a pipoca? Para descobrir, você tem que encontrar as flores. A pipoca, e todos os outros tipos de milho, têm dois tipos de flores: as masculinas, que produzem pólen, são marrons e ficam no alto do pé de milho; as flores femininas estão na espiga, que se forma nos cantos das folhas da parte de baixo da planta" (Jo Carr, 1982, p. 45).

Vemos o quanto todas as sugestôes feitas acima, de modo bem singelo e pragmático, envolvem necessariamente o apelo à imaginação das crianças, que é, por sua vez, como já vimos ao discutir o trabalho da professora que conta histórias, inseparável da linguagem.

Assim, enfatizamos mais uma vez que a imaginação, por sua importância como geradora de interrogaçôes e alternativas, "deveria ser vista mais apropriadamente como uma das nossas maiores ferramentas na busca do conhecimento objetivo e, na verdade, como aquilo que estabelece as próprias condições da objetividade". (Egan, 2007, p. 29). Se essa afirmação parece um tanto utilitária, lembremos que, ao mesmo tempo, a imaginação também é condição, propulsão e manifestação de toda a subjetividade, sendo por isso ligação entre sensibilidade e intelecto, entre ciência e arte.

A caminho da conclusão, retomamos a metáfora da imaginação como "clareira”, agora a partir de Eva Brann (1991), que destaca a complementaridade entre os modos do pensamento, sintetizando muito do que discutimos acima, em uma linguagem que é em si um exemplo do poder do enlace entre a exatidão referencial e a imaginação metafórica, na busca de dar conta dos processos humanos complexos:

A imaginação proporciona uma "clareira cognitiva" entre a percepção e a reflexão. [Nesse espaço], a experiência é consolidada a partir da acumulação de lembranças sensoriais. Ali são testadas possibilidades, através do livre jogo de 
visualizaçôes variáveis. Ali podem ser ensaiadas as questōes humanas e testados os sentimentos, longe das pressões da realidade imediata. [...] A imaginação, em todos os seus modos, pode cooperar na empreitada cognitiva e tomar parte dela. Primeiro, ela representa as aparências, clarificadas, dentro de seu próprio espaço; as absorve, embelezadas, em suas próprias visōes; as projeta de volta como transparências retificadoras sobre o mundo. E então cativa o pensamento, estimulando-o a perfurar esses panoramas imaginativos e a transcendê-los em busca de seu cerne invisível. (Brann, 1991, p.786).

A partir do esboço feito neste artigo, podemos dizer que a imaginação da criança é um modo de ver além ou de entrever, que intensifica a experiência do olhar e vice-versa. Como todos os sentidos podem despertar a emoção imaginativa, poderíamos também falar na imaginação como um modo de sentir além. As vivências imaginativas da infância têm um papel crucial no seu desenvolvimento estético, afetivo e cognitivo. Vimos que é possível atuar favoravelmente sobre a imaginação infantil, criando melhores condições para que as crianças disponham desse tempo ou lugar - metáforas para a imaginação - onde possam exercitar sua curiosidade sobre as coisas do mundo, constituir conhecimento sobre elas e sobre si próprias, e viver mais plenamente o imaginável.

\section{Referências bibliográficas}

ATALAY, B. A matemática e a Mona Lisa: a confluência da arte com a ciência. São Paulo: Mercuryo, 2007. 349 p.

BACHELARD, G. O ar e os sonhos: ensaios sobre a imaginação do movimento. São Paulo: Martins Fontes, 1990. 275 p.

BACHELARD, G. A água e os sonhos: ensaios sobre a imaginação da matéria. São Paulo: Martins Fontes, 1994. 202 p. [1989].

BARBOSA, M. C. S. Legislação e propostas curriculares: há lugar para a imaginação? In: FRITZEN, C.; CABRAL, G. S. (Org.). Infância: imaginação e educação em debate. Campinas: Papirus, 2007. 139 p.

BRANN, E. T. H. The world of imagination: sum and substance. Maryland: Rowman \& Littlefield, 1991.798 p.

BRONOWSKI, J. The common sense of science. Cambridge: Harvard University Press, 1978. $154 \mathrm{p}$.

CALVINO, I. Seis propostas para o próximo milênio. São Paulo: Cia. das Letras, 1990. 144 p.

CARR, J. (Org.). Beyond fact: nonfiction for children and young people. Chicago: American Library Association, 1982. 
CARROLL, L. Aventuras de Alice no Pais das Maravilhas. Trad. Jorge Furtado e Liziane Kugland. Rio de Janeiro: Objetiva, 2007. 166 p.

CHUKOVSKI, K. From two to five. 2. ed. Berkeley e Los Angeles: University of Califórnia Press, 1968. $170 \mathrm{p}$.

DE LAUWE, Marie-José C. Um outro mundo, a infância. São Paulo: Perspectiva; Edusp, 1991. $474 \mathrm{p}$.

EGAN, K. Imagination in teaching and learning: the middle school years. Chicago: The University of Chicago Press, 1992. 178 p.

EGAN, K. Por que a imaginação é importante na educação? In: FRITZEN, Celdon; CABRAL, G. S. (Org.). Infância: imaginação e educação em debate. Campinas: Papirus, 2007. 139 p.

GALEANO, E. O livro dos abraços. Porto Alegre: L\&PM, 2003. 270 p.

GARDNER, H. Art, mind and brain: a cognitive approach to creativity. New York: Basic Books, 1982.380 p.

GREENE, M. Releasing the imagination: essays on education, the arts and social change. San Francisco: Jossey-Bass, 1995. 221 p.

HELD, J. O imaginário no poder: as crianças e a literatura fantástica. 3. ed. São Paulo: Summus, 1980. 240 p.

JEAN, G. Los senderos de la imaginación infantil: los cuentos, los poemas, la realidad. México, D.F.: Fondo de Cultura Económica, 1990. 231 p. (1 $1^{\mathrm{a}}$ ed. em espanhol).

JUNG, C. G. Memories, dreams, reflections . Org. JAFFÉ, Aniela. New York: Vintage Books, 1989. 430 p. (1 ${ }^{\text {a }}$ ed. em inglês: 1973).

KEARNEY, R. The wake of imagination: toward a postmodern culture. 2. ed. Minneapolis: University of Minnesota Press, 1991. 467 p.

LATERMAN, I. Imaginação e ciência: para além da linguagem literal na comunicação do conhecimento. In: Trajetórias e processos de ensinar e aprender: lugares, memórias e culturas. ENCONTRO NACIONAL DE DIDÁTICA E PRÁTICA DE ENSINO, 24., Porto Alegre. Anais. Porto Alegre: EDIPUCRS, 2008. (1 CD-ROM).

MOCK, R. Education and the imagination. Londres: Chatto \& Windus, 1970. 136 p.

PIETROCOLA, M. Curiosidade e imaginação - os caminhos do conhecimento nas ciências, nas artes e no ensino. In: CARVALHO, A. M. P. de. (Org.). Ensino de Ciências: unindo a pesquisa e a prática. São Paulo: Pioneira Thomson Learning, 2004. 154 p.

RICOEUR, P. Imagination in discourse and in action. In: Analecta husserliana. Dordrecht, Holland; Boston e Londres: D. Reidel Publishing Company, 1978. v. 8.

RUSTIN, M.; RUSTIN, M. Narratives of love and loss: studies in modern children's fiction. London; New York, 1987. 268 p.

SHEDLOCK, M. L. The art of the story-teller. New York: Dover, 1951. 
SHEAFFER, C. I; GOLD, S. R.; HENDERSON, B. B. Environmental influences on children's fantasy. In: Imagination, cognition and personality. Amityville, N. Y. Baywood, n. 2, v. 6, 1986-1987. SINGER, D. G.; SINGER, J. L. Imagination and play in the electronic age. 2. ed. Cambridge, Mass. Harvard University Press, 2007. 210 p.

SINGER, J. L.; SINGER, D. G.; RAPACZYNKI, W. Children's imagination as predicted by family patterns and television viewing: A longitudinal study. In: Genetic Psychology Monographs, Worcester Mass: Clark University, n. 110, p. 43-69, .1984.

SLOAN, D. Insight-Imagination: the emancipation of thought and the modern world. 2. ed. New York: RCRE, 1993. 272 p.

VIGOTSKY, L. S. La imaginación y el arte em la infancia: ensayo psicológico. 6. ed. Madrid: Akal, 2003. 120 p.

WARNOCK, M. Imagination. Berkeley; Los Angeles: University of California Press, 1976. $211 \mathrm{p}$.

ZIM, H. S. Informational books: tonic and tool for the elementary classroom. In: ROBINSON, E. R. (Org.). Readings about children's literature. New York: David McKay Company, 1966. s/p. 